\title{
ADMiNiSTRATIVE RULEMAKING IN ETHIOPIA: NORMATIVE AND INSTITUTIONAL FRAMEWORK
}

Aron Degol and Abdulatif Kedir *

\begin{abstract}
Administrative action is steadily growing in Ethiopia, the major part of which is administrative rulemaking. It ranges from regulation of the major industries to the provision of basic commodities like sugar and edible oil. Modern states cannot effectively function without allowing the administrative agencies to have such roles, subject to the caveat that the agencies should to be kept in check by procedural stipulations and schemes. In this regard, there is gap in the Ethiopian legal regime due to the absence of administrative procedure law. This is a neglected subject both by the legal academia and practitioners. This article highlights the problems associated with the gaps in administrative law in Ethiopia and we argue that the prompt adoption of the Draft Federal Administrative Procedure Proclamation (2004) is necessary. The meaning of and the theoretical issues in relation to administrative legislation are discussed followed by the basic procedures and principles that should harness discretion and abuse of authority.
\end{abstract}

\section{Key words}

Administrative law, Administrative rulemaking, FDRE Constitution, Ethiopia.

DOI http://dx.doi.org/10.4314/mlr.v7i1.1

\section{Introduction}

Ethiopia has pledged to have a government limited by law, i.e. the principle of constitutionalism first through the 1991 Transitional Period Charter and then the 1995 Constitution of the Federal Democratic Republic of Ethiopia. This inevitably envisages certain standards of government. One of the areas of executive action that needs schemes of checks and balance is rulemaking or administrative legislation, which owing to various theoretical and practical reasons, allows the executive to make rules of general application.

Good governance presupposes universally accepted minimum procedures of administrative rule making. The absence of general administrative rulemaking

* Aron Degol (LL.B, LL.M) Lecturer, St. Mary’s University Faculty of Law; Abdulatif Kedir (LL.B, LL.M), Lecturer, Addis Ababa University, Center for Human Rights 
procedures in Ethiopia is indeed a striking scenario in the Ethiopian executive working environment. Another way of placing a controlling scheme on the exercise of power by the executive is institutional control by the parliament and courts as part of separation of powers. Moreover some watchdog institutions like human rights commissions and the Ombudsman institutions could also have a role.

The aim of this article is to highlight the problem associated with the absence of adequate normative rules in the Ethiopian legal system and the gap in institutional setup. To this end, the article starts with an introductory discussion on the functions of administrative law and highlights some of the theoretical objections to administrative rulemaking. The article further deals with some fundamental principles and procedures of administrative rulemaking and the controlling mechanisms that serve as background to the discussion of the Ethiopian case. Moreover, discussion is made on the expedience of legislation on general administrative procedures.

\section{Definition and Functions of Administrative Law and Administrative Rulemaking: An Overview}

There is variation in the definition of administrative law and administrative rulemaking. As the following brief discussion (on the core features of administrative law and administrative rulemaking) indicates, this is mostly attributable to the variation among legal systems as to what they consider to be within the realm of administrative law.

\subsection{Administrative Law}

Some British jurists define administrative law narrowly while others use broad definitions. ${ }^{1}$ Dicey observes that administrative law was unknown to British

\footnotetext{
${ }^{1}$ For instance, Robson defined administrative law as the law of public administration; see Robson, quoted in Upadhyaya, J.J.R., (2006), Administrative law, $6^{\text {th }}$ ed., (Central Law Agency, Allahabad, India) p. 2. Robson's definition seems to be circular that may have a negative impact on the clear understanding of the concept and nature of the subject. Administrative law should be regarded as the law relating to public administration, in the same way as commercial law consists of the law relating to commerce, or as land law is related to land. Dr. Port, in 1929, defined Administrative law as a branch of public law, which is made up of all those legal rules either formally expressed by statutes or implied in the prerogative-which have as their ultimate object the fulfillment of public law. According to Sir Ivor Jennings, Administrative law is the law relating to Administration. Neither Port nor Jennings defined Administrative law properly as the former described it and the later put it in a very general manner. See Jennings, (1959), Law and the Constitution quoted in Upadhyaya, J.J.R., (2006). Others like Albert Dicey understood it in a very narrow manner denoting only the portion of a nation's legal system which determines the legal status and liabilities of
} 
judges and counsel. ${ }^{2}$ In England, the system of administrative law and the very principles on which it rests were unknown until recently. ${ }^{3}$ This, however, does not mean that administrative law and its components are completely alien to England because the British parliament and the courts have always been and still are active in controlling the functions of administrative authorities. ${ }^{4}$

American scholars define administrative law within the context of their legal and justice system. ${ }^{5}$ Their conception of administrative law usually focuses on administrative rulemaking and the rule adjudicating aspects of administrative actions. Moreover, the American approach in defining administrative law emphasizes on one method of control; i.e. judicial control by seemingly undermining the control function of other organs.

In spite of such variation in perspectives, there are core functions that constitute the essential features of administrative law. Primarily, it has a control

all state officials. He regarded administrative law as the rights and liabilities of private individuals in their dealings with public officials and as a law that specifies the procedure by which those rights and liabilities are enforced; see Dicey, A.V., (1959), An introduction to the study of the law of the constitution, $10^{\text {th }}$ ed., (Universal Law Publishing Co. PVT. Ltd, Delhi, India) pp. 328-405. Dicey's formulation is based on the French Droit Administratif and, obviously disregards entities outside government agencies and authorities such as public corporations and public enterprises which under the Ethiopian legal system have their own legal personality and legal and institutional framework to be governed by. Ethiopian administrative laws do not regulate these enterprises. Moreover, Dicey's definition excludes how the administrative authorities are going to be controlled by other institutions like the legislative, the judiciary, the Ombudsman and the remedies/solutions for entities that might be aggrieved by the activities of these administrative authorities.

${ }^{2}$ Dicey, A.V., supra note 1, p. 330.

${ }^{3}$ Ibid.

${ }^{4}$ Fasil Abebe, "Notes on Administrative Law: French and English Experience", Mizan Law Review, Vol. 4 No. 1, March, 2010, pp. 160. See also Leyland, P., and Woods, T., (2002), Text Book on Administrative law, $4^{\text {th }}$ ed., (Oxford University Press, Delhi, India) p. 554, and Wade, H.W.R., and Forsyth, C.F. (2004), Administrative Law, $9^{\text {th }}$ ed., (Oxford University Press, Delhi, India), p. 9.

${ }^{5}$ K.C. Davis, for instance, defined administrative law as the law concerning the powers and procedures of administrative agencies, including especially the law governing judicial review of administrative action. See Davis, K.C quoted in Jayakumar, N.K., (2005), Administrative Law, (Central Law Agency, Allahabad, India) p. 5. Administrative law, in USA, is a law that governs the judicial control of administrative activities and procedures. In this regard, Davis's approach seems to be proper as it puts emphasis on procedures followed by administrative agencies in exercising their powers. This is not, however, to discount the role of the US Congress in directly or indirectly controlling administrative action through the power of the purse (budgeting) and others. 
function, acting as a brake or check in respect of the unlawful exercise or abuse of governmental/administrative power; it can also have a command function by making public bodies perform their statutory duties, including the exercise of discretion under a statute. Secondly, it has a facilitative function because it embodies principles that facilitate good practices in administrative functions toward ensuring that the rules of natural justice or fairness are adhered to. Administrative law provides for accountability and transparency, including participation by interested persons and parties in the process of government, and it provides a remedy for grievances occasioned at the hands of public authorities.

In Britain, administrative cases and matters used to be addressed in one basket with constitutional disputes/cases. There is no separate court/tribunal system and all matters were adjudicated by the regular/ordinary courts of the land. In the United States, much emphasis is given to the control of administrative actions only by one external organ; i.e. the judiciary, and more focus is given to procedural issues. ${ }^{6}$ Be this as it may, the understanding that guides the discussion in this article is that administrative law is a system of procedural rules and principles that regulates and guides the exercise of power by the executive organ of the state. More specifically, it deals with the regulation of the delegated rulemaking and adjudicative functions performed by executive organs.

\subsection{Administrative Rulemaking}

The American Administrative Procedure Act (APA) of 1946 states that "rule means the whole or part of an agency statement of general or particular applicability and future effect designed to implement, interpret or prescribe law or policy or describing the organization, procedure, or practice requirements of an agency ...". From this statutory definition, one can easily understand that rules are different from laws and policies. A rule is made for the purpose of implementing, interpreting, and prescribing laws and policies.

The Draft Federal Administrative Procedure Proclamation (hereinafter the Draft Proclamation) prepared by the Justice and Legal System Research Institute (JLSRI) in 2004 (1996 E.C) defines rules in a very similar manner with that of the APA. Article 2 (4)(10) of the Draft Proclamation defines 'rule' as a delegated legislation issued by an agency ${ }^{8}$ including the mode of operation of

${ }^{6}$ For an excellent discussion on American administrative law and procedure, see Peter L. Strauss (2002), Administrative Justice in the United States, $2^{\text {nd }}$ ed., Carolina Academic Press, North Carolina, USA.

7 The American Administrative Procedure Act (APA) of 1946.

8 The same draft instrument defined agency under Art. 2(2)(2) as an administrative agency with regulatory/supervisory power/function of the federal executive and a service rendering public office. 
the agency or the whole or a part of an agency statement of general applicability that implements, interprets, or prescribes law or policy, or the organization, procedure or practice requirements of an agency. The term includes the amendment, repeal or suspension of an existing rule. In the words of Oliver Wendell Holmes, "rule is the skin of a living policy that hardens an inchoate normative judgment into the frozen forms of words". Administrative rulemaking is, thus, the process/procedure involved in the making of administrative rules by administrative agencies in particular and of the executive branch of the government in general.

Characterizing a certain administrative act as an act of rulemaking has a number of implications, chief among them being the need to follow the procedures prescribed by law. Administrative laws (in the form of a code or scattered rules and principles) place a procedural requirement in exercising a given task; and in the event of non-compliance to the prescribed procedures, the specific decision of the agency would be void or contestable as the case may be.

Administrative rules are made by the executive under the powers delegated to it by the legislature. When the function of legislation is entrusted to organs other than the legislature itself, the legislation made by such organs is called delegated legislation. ${ }^{10}$ Therefore, as will be discussed later, administrative rules or delegated legislation do not fall within the ambit of the inherent constitutional powers/functions of administrative agencies as they are created only to execute the laws made by the proper lawmaking body. The power of making administrative rules is entrusted in administrative agencies by way of delegation from the lawmaking organ of the government.

The legislature delegates some of its lawmaking power to the executive organ due to various reasons such as parliamentary time, expertise/technicality of administrative matters, reason of secrecy, flexibility of administrative rulemaking procedure and emergency. It is analogous to an agency-principal relationship in which the principal authorizes the agent to perform some acts in his/her/ its behalf and for the exclusive interest of the same. The role of administrative agencies in any system of government is thus to bring down all the policies and general laws onto the ground and give them life. In spite of its importance and role, however, there is critique against the concept of administrative rules, as highlighted in the following section.

9 Cornelius M. K., (1997), Rule Making, How Government Agencies Write Law and Make Policy, (Universal Book Traders, Delhi, India), p. 3.

${ }^{10}$ Upadhyaya, J.J.R., supra note 1, p. 59. 


\section{An Overview of the Criticism against Administrative Legislation}

The realists consider administrative law as a law, while it may not be so for the positivists to whom law is strictly the one which is enacted by the legislative organ of the government as in the cases of contract law, criminal law, family law, or commercial law. As administrative law is not promulgated by the proper lawmaking body but by way of delegation, positivists like John Austin argue that "laws properly so called" must be distinguished from morals and other laws ${ }^{11}$ which, he described as "laws improperly" so called that lack force or sanction of the state. ${ }^{12}$

According to the classical and pure theory of separation of powers, each government unit must stick to the function/power entrusted to it. One organ must not interfere in the function of the other. The legislative wing of the government is empowered to make laws, which will be enforced by the executive and interpreted by the judiciary. Other than these, neither the executive nor the judiciary are allowed to perform tasks given to the legislative by a constitution, and if either of the two does so, then they will violate the constitution and the act will be declared invalid.

The British constitutional law jurist Albert V. Dicey, strongly criticized the French system of droit Administratif as it is against two important aspects of rule of law, which is one of the most significant constitutional principles; i.e. absolute supremacy/predominance of regular laws (as opposed to arbitrariness and discretion) and equality before the law. ${ }^{13}$ Dicey stated that rule of law means the absolute supremacy or predominance of the regular law as opposed to the influence of arbitrary power and excludes the existence of arbitrariness, of prerogative, or even wide discretionary authority on the part of the government. The other aspect of rule of law, for Dicey, is equality before the law. ${ }^{14}$ By this, he meant, equal subjection of all classes of citizens to the ordinary/regular law of the land administered by the ordinary/regular courts. ${ }^{15}$

${ }^{11}$ The words "... other laws", referred to administrative laws made outside the proper law making body.

12 John Austin (1883), 'The Province of Jurisprudence Determined" in Paranjape, N.V., (2001), Studies in Jurisprudence and Legal Theory, $3^{\text {rd }}$ ed., (Central Law Agency, Allahabad, India), p. 2.

${ }^{13}$ Dicey, A.V., supra note 1, p. 353. see also Jayakumar, N.K., supra note 1, pp. 5-6

${ }^{14}$ Ibid.

${ }^{15}$ Laws made by the proper lawmaking body designated by the constitution like the parliament in England or the National Assembly in France or HoPR in Ethiopia. 
France has a separate rule and statute of administrative law and procedure and a separately organized and structured institution; i.e. the Conseil d'Etat ${ }^{16}$ which, for Dicey, is against the principle of equality before the law as such a system creates differences that some classes of the citizens are going to be governed by a different law interpreted by a separately instituted tribunal. "If this is not against the equality aspect of rule of law, then what is?" asks Dicey.

Nonetheless, administrative rules and procedures have supporters because the contemporary concept of state is different from that of the former centuries when the function of the state was limited to four areas, namely maintaining peace and order, levying and collecting taxes, defending the sovereign nation from external invasion and administration of justice. ${ }^{17}$ The laissez-faire doctrine emphasized only on individual enterprise and limited the function of the state as much as possible. It considered the state as a facilitator and it gave much focus to the free enterprise of individuals, maximum contractual freedom and market forces that must determine the structure and flow of the socio-economic life of the nation. ${ }^{18}$

This type of state proposed by the apostles of this doctrine in the late $17^{\text {th }}$ and $18^{\text {th }} \mathrm{C}$., only had a facilitative role and was known as the 'Law and Order State'. ${ }^{19}$ However, such a limited role of the state in the socio-economic system and the concept of free enterprise and industrialization generated many problems, which were not foreseen by the adherents of the laissez-faire philosophy. The concentration of population in the cities, lack of proper facilities for accommodation for such population, unhealthy and dangerous conditions of work, and others were factors which necessitated relatively wider state involvement. These new developments thus paved the way for the decline of the laissez-faire theory. As Griffith and Street duly observed, "the very success of laissez-faire was its undoing". ${ }^{20}$

The failure of laissez-faire led to rethinking the role of the state in the socioeconomic life of the nation. It was realized that the activities of the state should not be confined to the traditional functions, but should expand to meet the new

${ }^{16}$ Literally, it means Council of State. It is empowered to adjudicate and resolve administrative litigations and disputes in France, see Freedman, C.E., (1961), The Conseil D'etat in Modern France, and Ducamin, B., (1981) Role of the Conseil D'etat in Drafting Legislation, ICLQ, Vol. 30.

${ }^{17}$ Jayakumar, N.K., supra note 1, p. 2. See also Leyland, P., and Woods, T., supra note 1 , pp. 5 and Scott \& Felix, (1997), Principles of Administrative Law, (Cavendish Publishing Limited, UK) p. 28.

${ }^{18}$ Jayakumar, N.K., supra note 1, p. 2.

${ }^{19}$ Ibid.

${ }^{20}$ Griffith \& Street in Jayakumar, N.K., supra note 1, p. 2. 
challenges. ${ }^{21}$ The popularity of humanitarian and socialist ideas accelerated the demand for state action in the field of social security. The state was also compelled to undertake planning and regulatory measures in the public interest. $^{22}$ As a result of the extension of franchise, the working classes became active participants in the political process, compelling the state to initiate as many welfare measures as possible. ${ }^{23}$

Freidman notes that the state began to function as protector and dispenser of social services, industrial manager, economic controller and arbiter. ${ }^{24}$ In other words, the state assumed a positive role and the concept of the social welfare state replaced the police state. As a result, there was a phenomenal increase in the area of state operation, and the activities of the state extended to all aspects of human life. ${ }^{25}$ The inevitable result of these changes was an increase in the powers and functions of the state. This was reflected in the three organs of the government, but the executive organ that was functionally the most suited to shoulder the major part of the new responsibilities, assumed a vital role in this process of transformation.

Nevertheless, there seems to be a different view which states that functionally, the executive was not a particularly apt repository for such new powers. This assumption, however, only envisages three organs of the state: legislative, judicial and executive, and the functions that overflow from the first two could only go to the third. ${ }^{26}$

Many functions, which were traditionally supposed to be within the domain of the legislature and the judiciary, came to be exercised by the executive. Such functions include the enactment of new laws that cannot be handled by the regular legislative body due to lack of time and expertise (technicality of the subject matter). Administrative agencies thus became the converging point of all types of government functions, including rulemaking. Stone calls this concentration of powers in the executive branch of the government; "the $20^{\text {th }}$ century administrative explosion," 27 and Robson named it "the hegemony of the executive". ${ }^{28}$

\footnotetext{
${ }^{21}$ Jayakumar, N.K., supra note 1, p. 2.

${ }^{22}$ Ibid.

${ }^{23}$ Ibid.

${ }^{24}$ Freidman, (1970), Law in a Changing Society, (Oxford University Press, UK) p. 378. See also Foulkes, David, in Jayakumar, N.K., supra note 1, p. 2.

25 Jayakumar, N.K., supra note 1, p. 2.

26 Julius Stone, (1966), Social Dimension of Law and Justice, in Upadhyaya, J.J.R., supra note 1, p. 8.

27 Id, p. 696

${ }^{28}$ Robson quoted in Upadhyaya, J.J.R., supra note 1, p. 59.
} 


\section{Principles of Administrative Legislation}

As has been discussed earlier, administrative rules/delegated legislation are made outside the proper lawmaking body; i.e. the legislative organ of the government. Unlike the ordinary laws or parliamentary enactments, they may not be required to meet the requirements of legislative procedures. This may have the tendency of paving the way for uncontrolled administrative discretion/ arbitrariness thereby jeopardizing individual rights and the constitutional order as a whole.

According to Hewart, unless the powers of the state are exercised according to law, it will ultimately lead to administrative despotism. ${ }^{29}$ In the long run, arbitrary power becomes despotism if the so-called administrative 'law' essentially amounts to lawlessness, when it is greatly extended; and this leads to the loss of those hardly won liberties, which it has taken centuries to establish. ${ }^{30}$ For this reason, certain principles have been developed and put in practice so that administrative rules may not encroach upon individual rights and freedoms. These schemes of protection and control against discretion and abuse are the principles of notice, public participation, publication, and control (in the forms of legislative control, judicial review and the ombudsman).

\subsection{Notice}

Notice is the first and one of the most important principles of administrative rulemaking. From the point of view of citizens affected, the primary safeguard to ensure the proper exercise of powers of administrative rules/delegated legislations lies in the development of adequate procedures to be followed by the administrative process in the formulation of rules and procedures as a means of obtaining participation in the process of making the administrative rules, and one of these means is notice. In some jurisdictions, it is known as Antecedent Publicity. ${ }^{31}$

For instance in India, there is no separate law relating to the system of antecedent publicity; however, in certain cases the various enabling statutes have provided for it. To this end, it is required that the administrative rules must be first published in a draft form to give an opportunity to the people to have their say in the rulemaking. ${ }^{32}$ Under such system, the authority must, first, publish a draft of the proposed administrative rules in the Gazette, secondly, the

29 Lord Hewart quoted in Upadhyaya, J.J.R., supra note 1, p. 59.

30 Ibid.

31 Upadhyaya, J.J.R., supra note 1, pp. 108. See also the Amharic expose de motif (explanatory note) prepared by the drafters of the Draft Federal Administrative Procedure code of Ethiopia p. 5.

32 Ibid. 
authority must invite objections and suggestions by a specific date, and third, the authority must take into consideration any objections and suggestions, which may be received by it while finalizing the rules. ${ }^{33}$

In the US, there is widespread use of the technique of antecedent publicity. Section 4 of the American Administrative Procedure Act of 1946 requires general notice of the proposed rule/s to be published in the federal register. The agency concerned must then provide the opportunity for the participation of interested persons through submission of written data, views and arguments with or without opportunity to present the same orally in any manner. ${ }^{34}$

In England, the system was provided for under the Britain Rules of Publication Act of 1893. Under Section 1 of this Act, public notice of proposals to make statutory rules was given, and the department concerned has to consider suggestions made by interested bodies, which were thus made aware of the proposed rules of which they otherwise might not have known. ${ }^{35}$ At present, however, Britain's new Statutory Instrument Act of 1946 that replaces the previous one, does not require antecedent publicity as a test of validity of an administrative rule though sometimes, especially, in individual cases, parliament may provide for antecedent publicity. ${ }^{36}$

Coming to the Ethiopian case, the Draft Federal Administrative Procedure Proclamation clearly obliges the administrative agencies to cause notice of their contemplated actions to be publicized in the newspaper or other means of Mass Media prior to the adoption of administrative rules. ${ }^{37}$ The draft proclamation also specifies the detailed content of the notice which shall include:

a) an explanation of the basis, purpose and rationale of the proposed rule,

b) the specific legal authority authorizing the proposed rule,

c) the text of the proposed rule,

d) where, when and how persons may demand an oral proceeding on the proposed rule, and

e) The location and availability of the rule making record. ${ }^{38}$

${ }^{33}$ Id, p. 107.

${ }^{34}$ Ibid.

${ }^{35}$ Ibid.

${ }^{36}$ Ibid.

${ }^{37}$ Chapter II, Art. 7 of the Draft Federal Administrative Procedure Proclamation of 2004 (1996 E.C).

${ }^{38}$ A rule making record is a document containing the full text of the rule that the agency made. The agency is legally obliged to maintain such an official document for each rule it proposes by publication in a newspaper and adopts. See art. 7(1)-(6) and Art. 14 of the Draft Proclamation. 
Unfortunately, however, this draft legislation on administrative rulemaking procedures, is not yet enacted as law and does not have a binding effect. No administrative agency in Ethiopia thus seems to bother about the pursuance of such procedures of notice to ensure the constitutional validity of its actions while making rules and directives.

\subsection{Public Participation}

An important scheme of check and control in the exercise of the power of delegated legislation/administrative rules is consultation through which entities that are likely to be affected may participate in the rulemaking process. This system makes administrative rulemaking a democratic process and therefore increases its acceptability and validity. ${ }^{39}$ Such public participation in the rulemaking process is a valuable safeguard as it enables the interests affected to make their views known to the rulemaking authority.

Wade and Philips rightly observed that one way of avoiding a clash between the department exercising delegated legislative power and the interest most likely to be affected is to provide for some form of consultation. ${ }^{40}$ As there is public participation, the technique of consultation is characterized as the democratization of rulemaking process ${ }^{41}$ and the rationale behind this technique is that legislation is primarily the function of the legislative wing of the government where various interests are represented. But if the rulemaking is done by an organ other than the legislative, there must at least be a provision for the affected interests to present their point of view to the concerned rulemaking authority, and definitely, this can be one of the means which, to some extent, can minimize the objection to bureaucratic and prevent an improper use of rule making power. ${ }^{42}$

In England, although there is no statutory provision which requires public participation and consultation of interests before the issuance of subordinate legislation, it is considered mandatory and no minister in his senses with the fear of parliament before his eyes would think of making regulations without giving persons who will be affected thereby or their representatives an opportunity of saying what they think about the proposal. ${ }^{43}$

\footnotetext{
${ }^{39}$ Upadhyaya, J.J.R., supra note 1, pp. 111. See also Craig, P.P., (2003), Administrative Law, $5^{\text {th }}$ Ed, p. 403.

${ }^{40}$ Wade and Philips quoted in Upadhyaya, J.J.R., supra note 1, p. 111.

${ }^{41}$ Upadhyaya, J.J.R., supra note 1, p. 111.

42 Jain and Jain, Principles of Administrative Law cited in Upadhyaya, J.J.R., supra note 1, p. 111.

${ }^{43}$ Griffith and Street, supra note 20, p. 56.
} 
In the US, the technique of consultation of interests (public participation) is very much in common use. Under the Administrative Procedure Act of 1946, there are detailed provisions for consultation requiring that interested persons should be given an opportunity to participate in the rulemaking process. ${ }^{44}$ In certain cases, Congress has made provisions for formal hearings and there is a general requirement of pre-publication of rules. ${ }^{45}$ Under such a system, parties likely to be affected are given an opportunity by the rulemaking authority to participate in the rulemaking process and the authority will consider the written data, views and arguments of those persons and finalize the rules. ${ }^{46}$ From this, one can simply understand that hearings preliminary to administrative rulemaking have become integral part of the American administrative process.

In India, there is no general statutory provision requiring prior consultation with the affected interests before making delegated legislation. ${ }^{47}$ While informal consultation is practised, certain statutes specifically provide for consultation and any person who is affected by an administrative directive of executive regulation can make suggestions or file objections. ${ }^{48}$ Such suggestions or objections will be considered by the rulemaking authority. There are four major types of consultation of interests under the Indian system of administrative rulemaking; these are:- official consultation, consultation with statutory boards, consultation with advisory boards, and making of draft rules by affected interests. $^{49}$

Consultation of interests through public participation can thus be a statutory safeguard against the improper use of rulemaking power in delegated legislation as it infuses democratic norms. This is indeed an administrative necessity because effective and meaningful administration is impossible without imaginative administrative processes.

\subsection{Publication (The Inner Morality of Law)}

Another equally established principle is the entitlement of the public to have access to the law and to an opportunity to know the law. It has been said that "all laws ought either to be known or at least laid open to the knowledge of all

\footnotetext{
${ }^{44}$ William Wade, (1988), Administrative Law (Oxford University Press), p. 884.

${ }^{45}$ Upadhyaya, J.J.R., supra note 1, p. 112.

${ }^{46}$ Ibid.

${ }^{47}$ Id, p. 113.

${ }^{48}$ Ibid.

${ }^{49}$ Ibid.
} 
the world in such a manner that no one may in impunity offend against them under pretence of ignorance". 50

As Lon Fuller observes, people cannot be expected to comply with rules of which they are unaware. ${ }^{51}$ Fuller strongly argues that any genuine system of law necessarily abides by certain moral principles which are called "The Inner Morality of the Law" ${ }^{52}$ A government can control and regulate the conduct of those in society in different ways. According to Fuller, a system of regulation and control is not a system of law, unless these principles of inner morality of law are satisfied.

These principles make up the inner morality of law, and are built upon the basic notion that law is something intended to regulate and control conduct by means of general rules that are addressed to humans as agents capable of deliberation and choice. ${ }^{53}$ Modes of regulation and control that do not rely on general rules or that bypass the human capacity for deliberation and choice are excluded and accordingly, legal rules must be applied prospectively, must be relatively clear in meaning and possible to comply with. ${ }^{54}$

Looking at the international experience, there is no unanimity regarding the mode of publication of administrative rules as a requirement in the administrative process. For instance, in England and the US, delegated legislation/administrative rules and directives are required to be published so as to enable the people to get knowledge about it. ${ }^{55}$ In India, the practice of publication of delegated legislation/administrative rules differs between statutes. Certain statutes require the rules to be published in the official gazette', while other statutes allow the relevant administrative authority to choose its mode of publication. ${ }^{56}$ In the practices of the three countries above, the mode, content and methods of publication are different. Nevertheless, the fact that any administrative rule or directive should be published and made known to the public is an important administrative procedure they all share in common.

${ }^{50}$ Bangndu Ganguly (1968), Administrative Legislation in Modern India (S.C. Sarkar), p. 74.

${ }^{51}$ Lon L. Fuller, (1969), The Morality of Law quoted in Ian McLeod, (2007), Legal Theory, $4^{\text {th }}$ ed., Palgrave Macmillan, New York, USA) p. 107.

${ }^{52}$ Ibid, See also Altman, Andrew, (2001), Arguing about law, An introduction to Legal Philosophy, $2^{\text {nd }}$ ed. (Wadsworth Publishing Company, Stanford, USA) p. 54.

${ }^{53}$ Id. p. 55.

${ }^{54}$ Ibid.

${ }^{55}$ Griffith and Street, supra note 20, p. 57.

${ }^{56}$ Upadhyaya, J.J.R., supra note 1, p. 109. 


\section{Controlling Mechanisms of Administrative Rulemaking 4.1 Parliamentary (Legislative) Control}

As highlighted above, administrative rulemaking activities are exercised by the executive unit of the government and such task is not within the natural power of the unit; rather it has been given to it by the legislative. Such delegated power entails a legislative oversight by the delegator which basically arises from two sources. The first justification is that the one that delegates should control the organ (that is delegated) as to how the latter is functioning, and the scope of the delegated power.

Secondly, parliamentary systems of government like Ethiopia and the UK usually put these entities (the parliaments) at the apex of power with the highest political authority of the state. This gives them the power to control and supervise all the remaining organs accountable to them. As Jain and Jain rightly pointed out:

$\ldots$ it is the function of the legislature to legislate, if it seeks to give this power to the executive in some circumstances, it is not only the right of the legislature but also its duty, as a principal, to see how its agent carries out the agency entrusted to it. Since it is the legislature, which delegates legislative power to the administration, it is primarily for it to supervise and control the actual exercise of this power and ensure against the danger of its objectionable, abusive and unwarranted use by the administration. ${ }^{57}$

The underlying object of legislative control is to keep watch over the rulemaking authorities and to provide an opportunity to criticize them if there exists an abuse of power on their part. This being the rationale for the lawmaking body to exercise its controlling and supervisory function over the rulemaking power of administrative authorities, the other equally important issue relates to the method and procedure of control.

Administrative rulemaking activities are supervised by the legislative organ in two ways. In India, for instance, the legislature can control delegated legislation effectively, first, by way of defining the limits of the delegated power clearly and precisely, and second, by examining whether they are within the limits that have been laid down. ${ }^{58}$ The first one that operates at the level of delegation is a rule of procedure requiring that a bill involving delegation of legislative power shall be accompanied by a memorandum explaining such proposals and drawing attention to their scope and stating also whether they are of exceptional or normal character. ${ }^{59}$ The other method is called laying on the

\footnotetext{
57 Jain and Jain, cited in Upadhyaya, J.J.R., supra note 1, pp. 99.

58 Jayakumar, N.K., supra note 1, pp.21

${ }^{59}$ Lok Sabha Rule 79, Rajya Sabha Rule No. 65.
} 
table, which is taken as one of the best devises of control. This method serves two purposes; first, it informs the legislature as to what rules have been framed by the administrative authorities in exercise of lawmaking power, and secondly, it provides an opportunity to the legislature to question or challenge the rules already made or that are proposed to be made, and such procedure is required to be followed in almost all commonwealth countries. ${ }^{60}$

There are several types in the application of this method, and the degree of control necessarily differs in these forms. ${ }^{61}$ Institutionally, again, the Indian system has set up a committee on subordinate legislation in each house of the Indian Parliament, and it pursues the model of the select committee on statutory instruments set up by the House of Commons in England in $1946 .{ }^{62}$ Each committee consists of 15 members and the chairman is generally the member of the opposition and government ministers are excluded from the membership of the committees. ${ }^{63}$ The main function of such committees on subordinate legislation is to scrutinize and report to the House whether the powers to make regulations, rules, sub-rules, by-laws, ${ }^{64}$ etc..., conferred by the constitution or delegated by parliament, are being properly exercised within such delegation. ${ }^{65}$

In performing their function, the committees, inter alia, examine (a) whether the delegated legislation is in accord with the general objective of the constitution or the parliamentary act pursuant to which it is made; (b) whether it contains matters which, in the opinion of the committees, should more properly be dealt with in an act of parliament such as levying tax, limiting jurisdiction of courts, etc.; (c) whether it appears to make some unusual or unexpected use of the powers conferred by the constitution or the parliamentary act pursuant to which it is made; and (d) whether for any reason its form or purport call for any elucidation. ${ }^{66}$ Through the years, the works of these committees have been very constructive and useful and have won acclaim from many that they are vigorous and independent bodies. ${ }^{67}$

${ }^{60}$ Upadhyaya, J.J.R., supra note 1, p. 100.

${ }^{61}$ Ibid.

${ }^{62}$ Jayakumar, N.K., supra note 1, p. 22.

${ }^{63} \mathrm{Id}, \mathrm{p} .23$.

${ }^{64} \mathrm{~A} \mathrm{By}$-Law is a rule of administrative provision, which is adopted by an association or corporation for its internal governance and includes all orders, ordinances, regulations, rules and statutes made by any authority subordinate to the legislature. Aiyar, P.R., (2006), Concise Law Dictionary, Wadhawa, Nagpur, p. 145.

${ }^{65}$ Jayakumar, N.K., supra note 1, p. 23.

${ }^{66}$ Rule 320, Rules of procedure and conduct of business in the Lok Sabha.

${ }^{67}$ Jayakumar, N.K., supra note 1, p. 23. 


\subsection{Judicial Control (Review by the Courts)}

Courts have a significant role in controlling the rulemaking powers of administrative bodies and in examining the validity of the rules because they are expected to be guardians of fundamental rights and freedoms. This judicial control over delegated legislation is called judicial review. The term 'judicial review' has different meanings and scope in different jurisdictions. For example, in the United States, judicial review refers to "the power of a court to review the actions of public sector bodies in terms of their lawfulness, or to review the constitutionality of a statute or treaty, or to review an administrative regulation for consistency with a statute, a treaty, or the Constitution itself' ${ }^{68}$ In the United Kingdom, the term judicial review refers to the power of the judiciary to supervise the activities of governmental bodies on the basis of rules and principles of public law that define the grounds of judicial review. It is concerned with the power of judges to check and control the activities and decisions of governmental bodies, tribunals, inferior courts etc. ${ }^{69}$

Such an institution controls the scope, necessity and validity of delegated legislation by applying two tests, namely: substantive ultra vires, and procedural ultra vires. ${ }^{70}$ When a subordinate legislation goes beyond the scope of authority conferred on the delegate to enact, it is known as substantive ultra vires. It is a fundamental principle of law that a public authority cannot act outside the ambit of its powers and if the authority acts, such an act would be ultra vires and accordingly void as has been rightly described by scholars to be the central principle and foundation of large part of administrative law. ${ }^{71}$

Procedural ultra vires is committed when a subordinate legislation is enacted without complying with the procedural requirements prescribed by the parent act (the principal legislation enacted by the parliament). In such cases, the courts may or may not quash delegated legislation depending upon whether the procedure is held to be mandatory or directory. ${ }^{72}$ In India and the United States, judicial control over delegated legislation through judicial review is exercised by applying the doctrine of ultra vires in a number of circumstances. For example, this applies "when the parent act or the general law itself is ultra vires

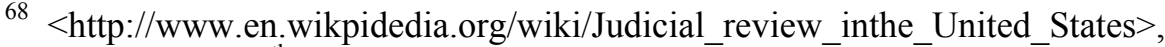
Accessed on $25^{\text {th }}$ February 2010.

${ }^{69}$ D. Longley, and R. James (1999), Administrative Justice: Central issues in UK and European Administrative Law, (Cavendish Publishing Limited, UK), p. 105.

${ }^{70}$ Ultra Vires (Latin) etymologically means beyond powers. If an act is done by an administrative authority in excess of power granted to it, the act is declared to be an ultra vires act.

${ }^{71}$ Durga Basu quoted in Upadhyaya, J.J.R., supra note 1, p. 87.

${ }^{72}$ Upadhyaya, J.J.R., supra note 1, p. 87. 
the constitution, or when the delegated legislation is ultra vires the constitution or when the delegated legislation is ultra vires the parent act". ${ }^{73}$

\subsection{Control by the Ombudsman}

Modern administrative systems have established a control and supervisory mechanism by external institutional frameworks such as the Ombudsman, which literally refers to the grievance man or a commissioner of the administration. ${ }^{74}$ This organ is deemed to be strong enough to prevent injustice to the individual while leaving the administration adequate freedom to enable it carry on effective government. ${ }^{75}$ The overall function of an ombudsman is to control and prevent maladministration in the government departments and its importance has also made it to be internationally acclaimed as one of the National Human Rights Institutions (NHRI) recognized by the Paris Principles of $1993 .^{76}$

The institution of the ombudsman was first recognized and established in Sweden which established the institution under its 1809 Constitution. Denmark also takes the credit along with Sweden. Especially, in 1954, the institution was introduced to the world by Denmark's first chief Ombudsman Prof. Stephen Horwitz, who played a vital role in making the institution very popular all over the world through his travel to many countries to introduce the significance of the institution. In the year 1960, the institution gained wider acceptance in other countries. At present, the ombudsman is not only a public entity, but it is also being established in the spheres of banking, insurance institutions and international/regional organizations. For instance, the Maastricht treaty which gave birth to the European Union in 1992 has a provision about the establishment of the ombudsman. ${ }^{77}$

Ombudsman varies from parliamentary and judicial control in three areas. First, it is independent and non-partisan which supervises the administration (executive). Second, it deals with specific complaints from the public against administrative injustice and mal-administration, and third, its power to investigate, criticize and report to the legislature is not backed by the power of reversing administrative action. ${ }^{78}$

${ }^{73}$ Alan Wharm, "Judicial Control of Delegated Legislation: The test of reasonableness", Madison Law Review Vol. 36, No. 611, 1973. See also Jain, M.P., "Parliamentary Control of Delegated Legislation in India", (1964), Public law Review, Vol. 33, p. 56.

${ }^{74}$ Upadhyaya, J.J.R., supra note 1, pp. 381-2.

75 Ibid.

76 Principles relating to the status and function of national institutions for the promotion and protection of human rights of the UN, G/A Res. A/48/134 of 20 December 1993

${ }^{77}$ For an excellent discussion on the historical development of ombudsman, see Leyland, P., and Woods, T., supra note 1, 142.

${ }^{78}$ Upadhyaya, J.J.R., supra note 1, p. 382. 
This institution is like a public safety valve against maladministration and it is meant to enhance good system of administration. It is thus required to be responsible and responsive to the people. Considering its importance, the Ethiopian parliament, has in accordance with Art. 55(14)\&(15) of the FDRE Constitution, established the institution alongside its twin organ, the Human Rights Commission in the year 2000. ${ }^{79}$ The objective of the Ethiopian Ombudsman is to bring about good governance, i.e., high quality, transparent and efficient administration based on the principle of rule of law that ensures the respect of fundamental rights of all citizens by the administration (the executive) ${ }^{80}$ The institution is given specific powers and responsibilities toward the achievement of its objectives. It is, inter alia, entrusted with the task of supervising administrative directives (administrative rules) issued by executive organs and their application so that they do not contravene the constitutional rights of citizens and the law. ${ }^{81}$

\section{Administrative Rulemaking in Ethiopia}

\subsection{A Cursory Look at Previous Constitutions}

The 1931 and 1955 constitutions (and the 1974 draft) did not contain any meaningful and practical limit on the power of government. The 1931 Constitution was simply a means of centralizing power of the Emperor, and, as Markaris notes, it was "designed as a legal weapon in the process of centralization of governmental power". ${ }^{82}$ The 1955 Revised Constitution showed little improvement in this regard as it tried to define and distribute powers of government among the various organs. It also included some provisions on fundamental rights and freedoms. But it failed to do away with the concentration of power in the hands of the Emperor as he shared lawmaking power with parliament. The Emperor also had some judicial powers which were stated in the constitution as the power to maintain justice. Moreover, the essential executive powers were vested directly on him. Under such constitutional set up, mechanisms of executive power control cannot exist because it would mean checking the unquestionable power of the Emperor.

79 The Institution of the Ombudsman and the Human rights Commission were established on the same day, by successive Proclamation No. 211/2000 and proclamation No. 210/2000, respectively. However, both institutions became operational five years after their official formation.

${ }^{80}$ Article 5 of Proclamation No. 211/2000 (Institution of the Ombudsman Establishment Proclamation.)

${ }^{81}$ Article 6(1) of Proclamation No. 211/2000

${ }^{82}$ H.Scholler (2005), Ethiopian Constitutional and Legal Development, Vol. I (Rudiger Koppe Verlag). 
Nevertheless, there were some attempts and signs toward addressing the grievances of citizens against maladministration. For instance, there was legislative effort to establish the Ombudsman during the last days of the Emperor's regime immediately after the upsurge of the 1974 revolution. The 1974 Draft Constitution devoted its ninth chapter to the establishment of the office of the Ombudsman. ${ }^{83}$ This draft, and thereby the establishment of the Ombudsman, remained in paper as a result of the fall of the Emperor in 1974. During the same period, an unsuccessful attempt was made to introduce for the first time an Administrative Procedure Law that was meant to govern the decision-making process of administrative agencies. The draft was not actually as comprehensive as the American Administrative Procedure Act since it failed to deal with the rulemaking procedures of the agencies. Its scope was limited to providing mandatory adjudication procedures of the agencies and the establishment of administrative court to review their decision. ${ }^{84}$

\subsection{Current Status of Administrative Rulemaking in Ethiopia}

The 1995 FDRE Constitution clearly stipulates that the council of ministers, which is the highest executive body in the government structure, is authorized, not by the Constitution but by the power vested in it by the legislative organ, to enact regulations. ${ }^{85}$ Lawmaking power is the constitutional responsibility of the House of Peoples Representatives (HoPR). Nevertheless, some of its lawmaking powers are delegated to the Council of Ministers because of the professional expertise in the executive and the need for efficient rulemaking regarding details. Not only is the executive branch authorized to enact regulations in general, but each department of the same branch is also given the power to make its own directives within the ambit of its power. Unlike the regulations issued by the Council of Ministers, which is clearly stated in the Constitution, we see no clear constitutional provision as to the delegated lawmaking power of each administrative organ of the government. Instead, whenever it is necessary to establish an administrative organ, the parliament will clearly state that the institution has the power of issuing directives, in the constitutive or subsequent legislation ${ }^{86}$ to implement the proclamations and regulations enacted by the Parliament and the Council of Ministers respectively. ${ }^{87}$

${ }^{83}$ Art. 143 of the 1974 Draft Constitution.

${ }^{84}$ Scholler, supra note 82 .

${ }^{85}$ Art. 77(13) of the FDRE Constitution of 1995.

${ }^{86}$ Legislation enacted by the parliament for the purpose of establishing an institution specifies its structure, powers and responsibilities, and is known as enabling legislation. Art. 34 of Proclamation No. 691/2010 (Definition of the powers and Duties of the Executive Organs of the FDRE) expressly empowers the Council of 
Unfortunately, however, while the legislative process pursued by the lawmaking organ used to be governed by a specific law; i.e. Proclamation No. $271 / 2002,{ }^{88}$ this proclamation was repealed and replaced by Proclamation No. 470/2005. ${ }^{89}$ Again, this proclamation is no more applicable as it was repealed by another third law; i.e. Proclamation No. 503/2006. ${ }^{90}$ This law not only repeals the law governing legislative procedures, but it totally abolishes the existing law without providing any substitute. As the preamble clearly indicates, the legislative procedure should be governed not by a proclamation to this effect but by an internal regulation of the House. As a result, the current law that governs the legislative procedure of the House is The House of Peoples' Representatives Regulation No. 3/1998. ${ }^{91}$ This regulation is not officially published and accessible to the public since it is an internal rule and procedure issued by the House as per Article 59(2) of the FDRE Constitution. ${ }^{92}$

Ministers to issue regulations for the establishment, reestablishment, dissolution, merger or division of any administrative agency in Ethiopia. In effect, the enabling act of parliamentary legislation my no longer be relevant and, administrative law in Ethiopia has now got a new face due to this provision.

87 Any enabling or substantive proclamation by the parliament contains such a clause. See for example, Art. 27(2) of the National Bank Establishment Proclamation (as amended), i.e. Proclamation No 591/2008; Art. 59(2) of Banking Business Proclamation No 592/2008; Art. 117(2) of Proclamation No. 286/2002 (Income Tax Proclamation) that gives the power to issue directives to the Ministry of Finance and Economic Development; and Art. 24 (2) of the Disclosure and Registration of Assets Proclamation No. 668/2010 that authorizes the Federal Ethics and Anti-Corruption Commission to issue directives necessary to implement the proclamation.

${ }^{88}$ House of Peoples Representatives Legislative Procedure, Committees Structure and Working Proclamation No. 271/2002.

${ }^{89}$ Federal Democratic Republic of Ethiopia House of Peoples' Representatives Working Procedure and Members' Code of Conduct (Amendment) Proclamation No. 470/2005.

${ }^{90}$ The Proclamation to Repeal the Amended Proclamation of the House of Peoples' Representatives Working Procedure and Members' Code of Conduct Proclamation No. 503/2006.

${ }^{91}$ The House of Peoples' Representatives of The Federal Democratic Republic of Ethiopia Rules of Procedures and Members' Code of Conduct Regulation No. 3/1998.

92 This regulation also controls the lawmaking process of administrative agencies by the parliament. Even in the absence of clear provisions of laying procedure and committee arrangement to supervise delegated legislation, the parliament could use Articles 55(17)\&(19) of the FDRE Constitution together with Art. 155(1)(a) of Regulation No. 3/1998 (The House of Peoples' Representatives of The Federal Democratic Republic of Ethiopia Rules of Procedures and Members' Code of Conduct Regulation). 
With regard to administrative organs, the Council of Ministers has issued an internal rule governing the working procedures of the council of ministers. ${ }^{93}$ Article 48 of the rule specifically deals with the process of preparing regulations. However, no formal legal rule is officially proclaimed/ published as to how each administrative agency, in particular, and the higher executive organ (the Council of Ministers), in general, should exercise delegated law-making power.

The notable exception in this apparent dearth of administrative procedural rules with regard to administrative legislation is Proclamation No. 590/2008 (Freedom of the Mass-Media and Access to Information Proclamation) which requires a public body to publish "the description of its regulations, directives, policies, guidelines and manuals which govern the operation and activities of its various organs along with the description of amendments or repeal of such provisions." This obviously helps in guaranteeing better access to the administrative rules once they are adopted.

However, there is ambiguity in the meaning of the requirement of publication, because it is not clear whether it refers to (a) publication in the official gazette as required by the Negarit Gazette Establishment Proclamation, (Proclamation No. 3-1995), or (b) publication in the government-owned newspapers such as Addis Zemen, or (c) whether mere duplication of the rules in many copies and making them available to 'clients' can be regarded as adequate.

\subsection{Status of Administrative Directives as 'Law', and the Requirement of Their Publication}

Article 2(2) of the Federal Negarit Gazzete Establishment Proclamation No. $3 / 1995$ stipulates that all laws of the federal government shall be published in the Negarit Gazzete. [Emphasis added]. But the proclamation is silent as to what constitutes 'law'. This, in its turn, will bring the issue of hierarchy of laws and the meaning of law under the Ethiopian legal system. Considering the arrangement and hierarchy of laws in Ethiopia, the Constitution is the supreme law. Next to it, we have parent legislation; i.e. parliamentary proclamations. They are primary legislation as they are promulgated by the direct representatives of the people. We also have subordinate/secondary/delegated legislation. These include administrative laws such as regulations of the Council of Ministers and directives issued by administrative agencies in the civil service.

The fundamental question that arises at this juncture is whether the term 'law' includes all these three categories of laws; i.e. proclamations, regulations and directives, or whether it only refers to primary legislation. This issue has

${ }^{93}$ Decision of the Council of Ministers of October 13, 2003. 
been addressed differently by different laws. ${ }^{94}$ But considering the hierarchy of laws and international experience, the term 'law' should include the three types of laws namely proclamations, regulations and directives as they are applicable on all subject matters they are meant to regulate and govern. Therefore, the definition of law provided by Article 2(2) Proclamation No. 251/2001 ${ }^{95}$ seems to be more appropriate than the others. It defines law as "Proclamations issued by the Federal or State legislative organs, and regulations and directives issued by the Federal and States government institutions and it shall also include international agreements that have been ratified By Ethiopia".

There have been three instances of publication of directives. The first is the directives issued for the determination of standard and according to Article 13(2) of Proclamation No. 49/1996 [Telecommunication Proclamation] ${ }^{96}$ the directives were envisaged to be published based on the directions of the [Telecommunications] Agency. The second is Article 6(6) of Regulation No. 194/2010 (National Metrology Institute Establishment Council of Ministers Regulation) with regard to the duty of Ethiopian National Metrology Institute to publish and declare to the public measurement units to be used in the country, symbols of the measurement units and national measurement etalons. The third bears the name 'regulation' but was actually a directive. It was issued by the National Electoral Board, signed by the then chairman of the board, and published in the Negarit Gazetta. ${ }^{97}$

${ }^{94}$ For example, Proclamation No.211/2000 defines law as "the Constitution of the Federal Democratic Republic of Ethiopia, the Constitution of a Region as well as federal or regional laws and regulations". According to Proclamation No 251/2001, law shall mean "Proclamations issued by the Federal or State legislative organs, and regulations and directives issued by the Federal and States government institutions and it shall also include international agreements that have been ratified By Ethiopia". As per Proclamation No 250/2001, law shall mean "the proclamations and Regulations issued by the Federal Government or the states as well as international agreements which Ethiopia has endorsed and accepted"; and Proclamation No. $25 / 1996$ defines law as "all previous laws in force which are not inconsistent with the Constitution and relating to matters that fall within the competence of the Federal Government as specified in the Constitution."

${ }^{95}$ A Proclamation to Consolidate the House of the Federation of FDRE and to Define its Powers and Responsibilities, Proclamation No. 251/2001

${ }^{96}$ Please note that some provisions (Arts. 3-9) of this Proclamation are now repealed. The rights and obligations of the Telecommunication Agency are now transferred to the newly established Ministry of Communication and Information Technology pursuant to Arts. 35(1)/d/ and 36(5) of Proclamation No. 691/2010 (Proclamation to Provide for the Definition of Powers and Duties of the Executive Organs of FDRE).

${ }^{97}$ National Electoral Board of Ethiopia Regulations No. 2/1999 (Determination of the Procedure for Expression by the Electorate of the Loss of Mandate of Deputies National Electoral Board Regulation). 
With regard to the binding effect of unpublished administrative directives, the Federal Supreme Court Cassation Division opined that although subsidiary legislation especially administrative directives are not published officially or written in foreign language, they are still binding since there is no mandatory legal requirement so far regarding their publication and it held that lack of publication shall not affect the binding effect of such directives. ${ }^{98}$ The court could have, however, considered the fact that directives fall under the term "law" as stipulated under Article 2(2) of Proclamation No. 251/2001 and that all laws should be published as required under Article 2(2) of Proclamation No. 3/1995 (Federal Negarit Gazetta Establishment Proclamation).

In another case, the Federal Supreme Court Cassation Division ${ }^{99}$ held that courts are required to take judicial notice of all laws including administrative directives since they are officially issued by the government. Here, the Court assumed that the mere issuance of the directives renders them 'official' as a result of which, the Cassation Division required courts to take judicial notice of such directives thereby disregarding the most important precondition of judicial notice; i.e. publication.

Another issue that substantiates the necessity of publishing directives relates to their effective date. Some directives issued by government agencies do not clearly indicate their specific effective date as a result of which, it is impossible to distinguish between the draft and the final directive. ${ }^{100}$ In some agencies, the date of the signature by the head of the issuing authority is taken as the effective date of the directives, which seems to be the practice in the directives of Ethiopian Revenue and Customs Authority. There are also agencies which expressly provide for the exact effective date of a directive. ${ }^{101}$

\subsection{Ambiguity, Language and the Processes of Issuance}

The absence of publication, public participation and notice in administrative rulemaking gives rise to serious problems. Such problems include vague delegation, approval procedures, language accessibility and the parliamentary

${ }^{98}$ Ethiopian Revenue and Customs Authority vs. Daniel Mekonnen, FSC Cassation Division File No. 43781, Hamle 14, 2002 E.C (i.e. July 21, 2010).

${ }^{99}$ Dandi Boru University College vs. Teklu Urga E. et al. FSC Cassation Division File No. 40804, Tir 26, 2001 E.C (i.e. February 3, 2009)

${ }^{100}$ An example in this regard is the Directive sent to Educational institutions with regard to the worship practice in educational institutions of Hidar 2000 E.C. (November 2007), containing no effective date, no signature or no seal of the Ministry.

${ }^{101}$ For instance, see directives issued by the Charities and Societies Agency, directives of Ethiopian Broadcasting Authority, directives of National Electoral Board and directives of the National Bank of Ethiopia. 
controlling system. Few statues require a directive to be approved by an internal higher authority such as a council or a board..$^{102}$ There is also lack of clarity in the manner of delegation and approval procedure of directives. In some instances it is not clear whether the specific agency is vested with the power of issuing the respective directive.

Moreover, there is a requirement of approval by "the government". The word 'government' is a general expression which lacks specificity whether it refers to the prime minister, the council of ministries, or the relevant ministry. The following illustrates this vague expression: ${ }^{103}$

"... employ and administer the employees of the agency/authority in accordance with the directives approved by the government following the basic principles of the federal civil service laws."

The other central problem is the issue of language. Almost all directives especially those affecting foreign investors and companies are prepared in Amharic. Almost all the directives of the Ethiopian Revenue and Customs Authority and the Ethiopian Investment Agency that affect the business undertakings of foreign investors are prepared only in Amharic. Few agencies like the National Bank of Ethiopia prepare their directive in English, and some other directives are prepared in both Amharic and English languages. ${ }^{104}$

There is no doubt that administrative rules (in the form of regulations of Council of Ministers or Administrative directives) are as important as the principal legislation (parliamentary proclamations) because they are issued to implement parliamentary laws. However, the process of their issuance, as stated above, is not uniform and this is bound to continue as long as their legislative process is not transparent and regulated by law and procedures. The current process not only creates confusion and inconsistent standards, but will also encroach upon the fundamental rights and freedoms of individuals. It also contravenes the FDRE Constitution with the risk of destroying the stability of

102 See Proclamation No. 720/2011 (the Ethiopian Federal Police Commission Establishment Proclamation), Proclamation No. 692/2010 (Federal Sport's Commission Establishment Proclamation), Proclamation No. 674/2010 (Pesticide Registration and Control Proclamation), Proclamation No. 571/2008 (Radiation Protection Proclamation) and Proclamation No. 495/2006 (Social Security Agency Reestablishment Proclamation).

${ }^{103}$ See for instance the Broadcasting Service Proclamation No. 533/2007; the Ethiopian Commodity Exchange Authority Establishment Proclamation (Amendment) No. 566/2008, National Educational Assessment and Examination Agency Establishment Regulation No. 260/2012; Catering and Tourism Center Establishment Regulation No. 174/2009; Civil Aviation Proclamation No. 616/2008.

104 The directives of the Ethiopian Electoral Board, Ethiopian Environmental Authority, and the former Ethiopian Telecommunication Agency. 
the constitutional system in general. The administrative rules briefly discussed in following section illustrate this point.

\subsection{Samples in Arbitrary Rulemaking}

\subsubsection{Abrogation of an employee's right to appeal against dismissal}

Following the restructuring of the executive organs of the Ethiopian government by Proclamation No. 471/2005, the former Ministry of Revenue has been reduced to the level of an Authority and re-named as the Ethiopian Revenues and Customs Authority (ERCA). The minister was re-assigned as Director General of the Authority. Based on this, the specific powers and responsibilities and other detailed matters concerning the Authority were addressed by another proclamation; i.e. Proclamation No. 587/2008. ${ }^{105}$ Pursuant to this law, the Council of Ministers was authorized to issue regulations; and it issued Council of Ministers Regulation No. 155/2008 on the administration of the Authority's employees. $^{106}$

Disciplinary matters of any employee are governed by Articles 34 and Article 35 of the Regulation, and there are prescribed procedures to be employed before rendering a decision on the employees of the authority. ${ }^{107}$ If an employee of the authority is suspected of corruption by the Director General of the Authority, the latter can dismiss the employee without the need of going through the whole procedure of taking disciplinary measures, and what makes it worse is that an employee, dismissed under these circumstances, has no right to be reinstated by any judicial decision. ${ }^{108}$

The Regulation clearly contravenes the 1995 FDRE Constitution for three reasons. First, it clearly violates the constitutional rights of access to justice enshrined under Art. 37 of the FDRE Constitution. Regular courts are said to be

105 Ethiopian Revenues and Customs Authority Establishment Proclamation No. $587 / 2008$.

106 This is a clear departure from the Federal Civil Service Proclamation No. 515/2007 that employees of the Authority are now treated differently in every aspect though they are still civil servants. Please also note that such a special treatment (positive and negative) is given by a regulation, which is lower than a proclamation in the hierarchy of laws.

107 These provisions and the procedures incorporated in the new Civil Service Proclamation; i.e. Proclamation No. 515/2007 fail to clearly state and guarantee the constitutional rights of employees to be heard (fair hearing); Compare Art. 69 of Proclamation No. 515/2006 and Art. 34 Regulation No. 155/2008 with the previous Federal Civil Servants proclamation No. 262/2002, Art. 67(2).

${ }^{108}$ Art. 37 of Regulation No. 155/2008. 
guardians of rights and freedoms, and unless individuals are guaranteed and guarded by such courts, such rights become superfluous and nominal.

Second, judicial independence, a fundamental constitutional principle, is violated because the Regulation takes away the power of the courts and confers it to an administrative entity. This violates Article 78(4) of the Constitution which provides that "special or ad hoc courts will never be established that will take judicial powers away from the courts or institutions legally empowered to exercise judicial functions and do not follow the prescribed procedure". However, the authority under consideration is not an institution legally empowered to exercise judicial functions. Nor did it follow legally prescribed procedures.

Thirdly, such rules clearly violate a fundamental principle of administrative law known as "Nemo Judex in Causa Sua" (in Latin), which means that "no one should be made a judge in his/her own case." The Ethiopian Revenues and Customs Authority, by enjoying such a power, clearly takes the law in its own hands thereby acting in dual capacitates as the plaintiff and the judge in its own case at the same time. Moreover, It is to be noted that an employee who is dismissed on the basis of Regulation No. 155/2008 automatically loses his/her social security, which entails the failure of the government to fulfill its constitutional obligation to promote the health, welfare, living standards and social security ${ }^{109}$ of such citizens.

One may argue that administrative agencies should, as of necessity, have adjudicative power. However, such function is entrusted in administrative organs by at the same time putting in place a setting in which the functional independence of the administrative entity entrusted with the adjudicative task is assured. Council of Ministers Regulation No. 155/2008 thus violates due process of law which requires any measure or government decision to be in accordance with the prescribed procedures of the positive laws in the absence of which arbitrariness will reign.

\subsubsection{Banned enrolment to private HEIs in the fields of law and teacher education}

The August 2010 Directive of the Ministry of Education has banned the enrollment of new students to private higher education institutions (HEIs) in the fields of law and teacher education. The Directive states the reasons why it suspends some other educational sectors like Distance education (a measure that

${ }^{109}$ Art. 89(8) and Art. 90(1) of the FDRE Constitution. Based on such regulation, i.e. Council of Ministers Regulation No. 155/2007, the Director General of the Ethiopian Revenue and Customs Authority (ERCA) has dismissed 49 employees suspected of corruption during the first quarter of the 2003 E.C fiscal year. (Addis Zemen Newspaper $70^{\text {th }}$ year No. 83, Hidar 23/2003 (December 2, 2010), pp. 1 \& 12. 
has been lifted in due course), the opening or expanding of new branches and new fields of studies etc. However, it does not state the reason/s why student enrollment in law and teacher education is banned. ${ }^{110}$

If the title of the Directive that reads the 'Directive Issued to Ensure the Quality and Relevance of Higher Education and TVET', implies inferior quality of private higher educational institutions in the legal and teachers' education streams, there should have been a distinction among private Higher Education Institutions which offer law and teacher education programs. Moreover, law and teacher education programs of some public universities should have been banned or suspended.

There is also the query as to why law and teacher education are singled out, while medicine is pertinent to the life of citizens, and engineering constitutes one of the pillars for every aspect of Ethiopia's developmental pursuits. As quality cannot be sectoral based on private/public dichotomy, any measure of banning or suspension should not have been based on a public/private divide, but on the basis of the quality audits of HERQA (Higher Education and Relevance Quality Agency). Moreover, such the ban or suspension should have applied to both public and private higher education institutions in professions such as medicine, engineering, law, teacher education, and others as well.

Graduates from all sectors (whether public or private) serve the same public upon graduation, and such measures should not have taken 'ownership' models of the institutions as yardsticks, but should have rather been based on the quality and standards of educational service delivery. If the directive had a counterpart in USA, law schools such as Harvard and Yale would have been banned.

Article 25 the FDRE Constitution clearly states that all persons are equal before the eyes of the law, and these persons ${ }^{111}$ are entitled to equal protection of the law without any discrimination of any kind. Thus all organs of the government (the legislative, executive and judiciary) both at the federal and state levels have the constitutional duty and responsibility to respect and enforce this constitutional provision. ${ }^{112}$ On the contrary, the Ministry of Education has violated this constitutional right of citizens by issuing such a discriminatory directive. Had there been an administrative rule making procedure, such a directive would not have been issued or could have been promptly reviewed by the relevant organs.

${ }^{110}$ Sec. 2(5) and Sec. 3(3) of the directive.

${ }^{111}$ Private higher educational institutions are legal persons before the law.

${ }^{112}$ Art. 13(1) of the FDRE Constitution reads: "All Federal and State Legislative, Executive and Judicial organs at all levels shall have the responsibility and duty to respect and enforce the provisions of this chapter", i.e., the third chapter that embodies Articles 13 to 44 which address fundamental human and democratic rights. Article 25 is one of these constitutional provisions under the third chapter. 


\section{Concluding Remarks}

Administrative agencies are susceptible to abuse of authority in relation to the purse and the gun under their control. Schemes of balance, check and control are thus very essential over these agencies including clear procedures which should harness administrative rules, directives and their implementation. In the absence of such clear and strict procedures, substantive rights and freedoms of citizens are vulnerable to series of infringements.

These procedural rules of administrative legislation have a dual purpose: first, they prevent the issuance of administrative directives that may encroach upon the fundamental rights and freedoms. Second, they help the government to check itself and correct any mistake and mitigate incidences of administrative abuse. Administrative agencies erode their democratic legitimacy and can be susceptible to substantive and procedural abuse of power unless their rulemaking functions are harnessed by publicity of the draft rules before issuance, participation of stakeholders in public discussion about the draft administrative rules, publication of the rules, parliamentary control and judicial review.

In light of the Ethiopian current situation, the expedience of administrative rules is apparent. This is indeed compounded by the increasing role of the Ethiopian government as a result of the 'developmental state' theory it has pledged to pursue because such pursuits significantly enhance the role of the state in the economic and social sectors. 